\title{
INTERPRETIVE STRUCTURE MODELLING FOR CHALLENGES OF MAN POWER PLANNING IN A SMALL SCALE INDUSTRY
}

\author{
Ashok Kumar (Student M.Tech) \\ Mechanical Department \\ J.C BOSE YMCAUST \\ Faridabad Haryana India
}

\author{
Dr. Vikram Singh (professor) \\ Mechanical Department \\ J.C BOSE YMCAUST \\ Faridabad Haryana India
}

\begin{abstract}
The small scale manufacturing industry faces many challenges in market such as price, quality of a product, manpower planning, and funding problem. The excellence operation and effective utilization of manpower and machine are the key factor to over-come the problem. The accurate forecasting of the manpower and effective utilization of manpower to overcome this problem. This research recommended to small-scale industry improves their utilization of manpower in order to improve effectiveness and efficiency day to day. Improve their daily activity in order to achieve their targets. The planning of manpower ensure that adequate supply, right quantity of manpower at right time, at right place. This paper develop an ISM model for a man power planning in a small scale industry.Interpretive structural modeling is one of the wellestablished methodologies for identifying relationships among specific items and which defines the problems of an issue. This approach has been used by various researchers to represent the interrelationships among various elements related to the issue.
\end{abstract}

Keywords: Manpower, ISM, MICMAC Analysis,

\section{INTRODUCTION}

Manpower planning in an industry is foremost for the sustenance of the industry and deals in the growth in the productivity of the industry by better utilization of the most critical asset of the industry i.e. the manpower. In a small-scale industry, manpower planning increases its significance multifold wherein the productivity of the organization is mainly based on the proper utilization of the available manpower resource. It has been seen that a country's prosperity is directly linked with the prosperity among the workers in Medium and Small Scale Industries, who are the driving factor of an economy and present in masses. Effective manpower planning needs several levels of approaches, which have been dealt in detail in the present thesis. The thesis deals and analyzes the approach by way of constructing a model on how to effectively utilize the manpower by means of scientific analysis. It stresses on the relationship between the driving factors with the dependency factors in an industry and examines its interdependency.

\section{PROBLEM STATEMENT}

In small-scale industry, production schedule is delayed due to different reasons there is some delay in production due to a variety of reasons viz. delay in procurement and availability of raw material, machine break down, loss in manpower hours due to ineffective manpower planning.

\section{OBJECTIVE}

Aim of this thesis is to identify the following:

(i) Identify the factors, which are affecting the manpower planning in small scale industry.

(ii) To develop a model using an Interpretive Structural Modelling technique for a small-scale industry by plotting a graph between driving power and dependence power.

\section{SCOPE}

(i) To identify the factors affecting manpower planning. (ii) To generate an ISM model for prioritising factor affecting manpower planning.

(iii) To plot an ISM graph for taking decision in effective utilisation of manpower.

\section{LITERATURE REVIEW}

Manpower must do significant job for stead expeditious development of economic 


\section{International Journal of Engineering Applied Sciences and Technology, 2019 \\ Vol. 4, Issue 4, ISSN No. 2455-2143, Pages 365-377 \\ Published Online August 2019 in IJEAST (http://www.ijeast.com)}

advancement of a nation. Because of this reason, point of the Ministry Of Human Resources to subsist plans the arrangement for viable use the HR accessible all through the nation for their development and nation's Development.

Manpower usage influences the other control as financial aspects, brain research, law and open company Manpower planning is a sophisticated process. So that before manpower planning lot of literature steady required. Now a day's challenge of manpower planning and optimum use such that economic grow. Research is going on in each field for their improvement and manpower planning does not persevere behind.

- Zaini Abdullah, Nilufar Ahsan and Syed Shah Alam et al (2009) proposed that training methodology and team work have positive impact on the organisation, and analysed the performance of the organisation, before the tanning and after the tanning.

- Adekunle et al ( 2014) explained that the manpower planning is a process by which an organization gets required no. of people for the desired work on time, also explained about the reduction of labour cost and eliminated the chance of the of excess staffing. It also focuses on the important issues on manpower planning.

- Mohammad Tufail khan et al (2018) explained the importance of man power planning in the education sector and also explained the various steps that are to be adopted in manpower planning.

- Koltnerová, Kristína, Andrea Chlpeková, and Jana Samáková et al (2012) explained the human resource planning can help in forecasting the man power requirement in the future, also for optimum utilization of the human resource also explained that the success of the organization basically depends on factors like right number of people with right skills and at right time.

\section{METHODOLOGY}

The first objective to identify the driving factors, which are affecting evaluation of manpower planning in a small-scale industry. After the literature review and questionnaire of expert is to identify the factors. The second objective is to develop a model using an interpretive structural modelling technique. Based on the model, a graph was plotted between the dependency of identifiable factor and driving power of the identifiable factor.
The first step identifies the important barriers wherein the experts taken into consideration has their range of experience between 5 to 30 years. The second step establishes the relationship between the dependency, which is based on relationship among identifiable factors, and driving power, which signifies the effectiveness of the manpower planning.

\section{CHALLENGES OF MANPOWER PLANNING IN SMALL SCALE ORGANIZATION}

Obasan and Yomi et al, in its paper titled "Conceptual Approach to Manpower Planning in Organizations" in 2011 has outlined the problems of effective manpower planning and has made its observation to include - politicization of manpower planning effort, manpower planners, dearth of professional trained, lip service paid to manpower planning, lack of commitment by stakeholders and inconsistency in government policies. Manpower planning is seen as a conscious and rational decision making process geared towards defining the various courses of action that need to be carried out within an organization. Accordingly, some of the reasons for these failures are discussed below:

8.1. Lack of Communication: It is one of the established issues and is of basic nature in an organization. Manpower planning is a sophisticated procedure, wherein the positioning is done by the specialists. The experts collect real time and exact data from the organization. With the end of the result, if any issue emerges, suitable move is made. Okhakhu and Adekunle et al (2013) suggested a correspondence channels to be proper and accommodative input. This may help a lot in having comprehensive and functional manpower plan for the organizations. Absence of correspondence issue makes for effective manpower planning.

8.2. The Lack of Sensitivity to Problems and Solutions of issues: The major roadblock to the implementation of effective manpower planning is brought about by the general line administrators. The executives is mainly worried about monetary and material assets and tends to disregard the basic factor of Human resources. In the recent decades, efficiency of the manpower has expanded because of improved innovation and creation, yet any further improvement will depend on the various agile parameters. Due to several issues, the executives demonstrate a more noteworthy regard to the job of labour in seeking after and accomplishing authoritative objectives and goals. If by chance, any issue emerges and note heeded to 


\section{International Journal of Engineering Applied Sciences and Technology, 2019 \\ Vol. 4, Issue 4, ISSN No. 2455-2143, Pages 365-377 \\ Published Online August 2019 in IJEAST (http://www.ijeast.com)}

promptly, the issues goats aggravated, and needs a major course correction approach.

8.3. Short Term Profit Goals: In the short-term, it is necessary to view manpower planning for effectiveness such that the labour can be arranged effectively according to their requirement for present scenario, cost increment, and cost planning e.g., expenses of faculty, overhead costs, indirect cost , direct recurring costs. It is fundamental the administration survey the issue, and gauge the advantages against the expenses. This absence of worry over labour arranging could be ascribed to the absence of data. In the event that data isn't prospective, at that point labour arranging is a rogue workout. It is accordingly basic that associations obtain imperative data that will stay up with the latest in their different exercises.

8.4. Complexity of the Organization: Many associations have expanded massively as compared to the previous year and a few people seem to experience issues in deciding the different sizes of the labour group. They give off an impression of being unequipped for refreshing the retrievable data, which is basic to labour arranging. In light of the expanding intricacy of associations, it is ending up progressively basic to keep a track on the development of the labour.

8.5. Rapid changes : Rapid changes in technology in the concerned sector of organization effects manpower planning because some time is required for the worker to learn new things, gets accustomed to the new technologies, best method of training is required for the worker. One possible method of overcoming this resistance to change on the part of the existing staff is to introduce new employees, with new ideas from outside of the organization and the worker to be given formal training in the changed scenario.

8.6. Working environment: The working environment plays a major role for manpower planning. Workers always prefer to work in a conducive environment. Some facilities via proper ventilation, fan, cleaning, air, and lighting, dust free shop floor are always a pleasant option for the workers to enhance their productivity.

Workers always expect good behaviour from staff members. If staff members politely talk to workers, then workers think about industry and attaches themselves to the organization with an emotional bond and work more efficiently. Various psychological changes in the worker could create a good environment.

8.7. Absenteeism: Those workers who are not regular, the efficiency drops to approximately half.
If not working properly and quality being not maintained, the major impact goes on manpower planning. Human resources department assume normal days to be $10 \%$ workers absent and festival season approximately $20 \%$ worker absent. In this case, new workers are recruited who are unskilled. The workers have no idea about work. It is the major problem to provide individual training to the worker. The new worker takes more time to settle down and efficiently resume to work. Therefore, absenteeism is one major concern, which influences manpower planning.

8.8. (i) Wages/salary as per government norms: Wage is a very sensitive factor for manpower planning. Amount paid at regular intervals especially by the day to day or weekly or monthly for time during which worker is employed is known as salary. According to Government laws and legislations such as Minimum wages Act, payments of wages Act, etc. which is taken into consideration seriously, and implementation of their own policies on salary and wages. They have to be satisfying the legal requirements.

Current going wages and salary in the country; the salary paid by the neighbouring companies for the similar type of a job. Before they implement their own wage policy, they should take into consideration, competition's, company's salary. Supply and demand of labouring the case of shortage of manpower they should keep flexibility in the wage structure.

(ii) Time of salary: Salary should be provided to the workers on time, because workers depend on salary to fulfil their day-to-day needs. If salary is not provided on time than he/she could not pay timely rent and they will face day to day problems. In that case, they will leave the company and join another company.

8.9. Job security: Worker expects job security from the company. The company has to provide facility to both permanent and temporary workers. If the worker has completed a certain amount of time with the company viz. a year or two year's periods, they should be provided permanent employee status

8.10. (i)Loan facility: Loan facility plays a major role in holding the employee. Some small skill industry provides loan facility but major smallscale industry does not provide loan facility. Employee expected loan facility to fulfil their immediate requirements, which arises due to certain exigencies. Loans with minimal rate of interest binds the employee to the organization as the employee feels morally indebted to the organization as it acted in the time of the worker's needs.

(ii)Medical facility: The workers expect medical facility from the company. If the company did not 


\section{International Journal of Engineering Applied Sciences and Technology, 2019 \\ Vol. 4, Issue 4, ISSN No. 2455-2143, Pages 365-377 \\ Published Online August 2019 in IJEAST (http://www.ijeast.com)}

provide medical facility, eventually the worker will leave the company. Further, medical facilities bring in a bond of security with the workers. The manpower's working with the environment works in a free manner assuming that he is covered under some or other medical cover which will take care of him in case of medical exigencies.

(iii) Bonus: The workers want bonus time to time as it helps them in saving some money for future use. Bonus impact on manpower planning which is a motivating factor for the workforce. Bonus at the time of festivals takes care of the workers special needs during the festivals.

8.11. Safety equipment: If safety equipments are not provided by the company, than worker face many problem and after some they time leave the company. Further, safety equipment ensures defect free product thereby increasing the revenue growth in the long run. A safe and secure employee gives his best service to the organization, which becomes an asset in due course of time.

8.12. (i) Working time/shift: Generally workers want to work in day shift as it does not effect and keeps them in good health condition. In the night shift, workers do not prefer to work. Change in shifts creates undue life style changes in the workers, which directly or indirectly takes a toll on the working capability of the worker, thereby reducing the productivity of the organization in the long run.

(ii)Over time: Workers expected overtime 2 to 3 hours daily because it helps in some extra earning. Workers use over time salary for rent, travelling and others personal works. If workers do not get an over time for the extra work done, it may compel them to search for new opportunities.

8.13. Training facilities: Workers expect training facility provided by the company such that he learns new technology and gain some skills. After the training, he converts unskilled to skilled worker and his earning capability increases. A skilled employee becomes an asset for the company, who are in demand. Regular and correct training, imparted to a worker increases his productivity many fold which has proportional relation to the company's growth. .

8.14. Attitudes of workers: Workers' attitude defines the approach towards the work assigned to a worker at the instant. It is one of the contributing factors while deciding the manpower planning. It is seen that the workers who are available in the vicinity of an organization are abundant; however, their attitude at work is generally not so encouraging. Further, the Local workers available also cast aspiration on the workers coming from far-flung places, and available at cheap rates. The government regulations favouring regional aspirations also contribute to a factor on the rough attitude of workers. This factor, therefore, must be taken into account while manpower planning.

8.15. Earned Leaves/Casual Leaves/ Loss on Pay Leaves: Workers expect some yearly leaves and consider it as their rights. Leaves can be segregated into earned leaves, whereby a worker is granted a specific period of days of leaves, for which the organization has to pay the worker. Further, in certain exigencies, a worker needs to take urgent leave, which can be classified into casual leave, wherein the organization grants a defined period of paid leave, yearly. If in case, a worker needs an extended period of leave, there should be provision to grant the leave, but the organization need not pay for the leave, as it would mean paying to workers without any work. However, these leaves are a part of manpower planning of an organization, and should be given, so as to keep the worker motivated and give them time to balance their work and personal life.

8.16. Availability of basic needs such as Drinking water, Tea, First Aid etc: In any organization, particularly a small-scale industry, micro management of the resources plays a major role in retaining the talent pool. Availability of first aid kit according to the working environment is one of them to make the worker feel secure. Potable drinking water, tea-snacks, etc are among the other items to be considered so as to give employee a mid-break of few minutes and further make them feel that the organization they are working for is taking proper care of their basic needs. These small items of consideration make a major impact on the psychology of workers, which may attract or distract the workers, particularly in a small-scale industry, towards the industry.

TABLE: 1 LIST OF BARRIERS OF MANPOWER PLANNING

\begin{tabular}{|l|l|l|}
\hline S. NO & BARRIERS & AUTHORS AND EXPERT OPINION \\
\hline 1 & Lack of Communication & Okhakhu and Adekunle (2013) \\
\hline 2 & $\begin{array}{l}\text { The Lack of sensitivity about problem and } \\
\text { solution of the issues }\end{array}$ & Adiele, 2006 \\
\hline 3 & $\begin{array}{l}\text { Short Term Profit Goals } \\
\text { Organization }\end{array}$ & Adekunle, S.A.(2014) \\
\hline 4 & \begin{tabular}{l} 
Oack of Criteria\& Complexity of the \\
\hline
\end{tabular} & Okhakhu and Adekunle (2013) \\
\hline
\end{tabular}


International Journal of Engineering Applied Sciences and Technology, 2019

Vol. 4, Issue 4, ISSN No. 2455-2143, Pages 365-377

Published Online August 2019 in IJEAST (http://www.ijeast.com)

\begin{tabular}{|l|l|l|}
\hline 5 & Rapid change & Adekunle, S.A.(2014) \\
\hline 6 & Working environment & Expert view \\
\hline 7 & Absenteeism & HR opinion \\
\hline 8 & $\begin{array}{l}\text { Wages/salary as per government norms\& Time } \\
\text { of salary }\end{array}$ & Expert view \\
\hline 9 & Job security & Pfeffer(1998) \\
\hline 10 & Loan facility\& Medical facility\& Bonus & Expert view \\
\hline 11 & Safety equipment & Engineering opinion \\
\hline 12 & Working time/shift\& Over time & HR opinion \\
\hline 13 & Training facility & Zaini Abdullah, AhsanAlam(2009) \\
\hline 14 & Attitudes of workers & Plant head opinion \\
\hline 15 & $\begin{array}{l}\text { Earned Leaves/Casual Leaves/ Loss on Pay } \\
\text { Leaves: }\end{array}$ & Worker opinion \\
\hline 16 & $\begin{array}{l}\text { Availability of basic needs such as Drinking } \\
\text { water, Tea, First Aid etc }\end{array}$ & Worker opinion \\
\hline
\end{tabular}

\section{ISM APPROACH}

Table: 1 influential roles of important 16 barriers are identified using ISM approach. Basic steps involved in ISM approach is discussed below:

Warfield (1974) introduced ISM approach which is used to stab list the interrelation between factors given in list and identify the influential role of the identified factors. This approach is made by experts, using various techniques like nominal technique, brainstorming etc

\subsection{Steps involved in ISM approach are as} follows:

STEP 1: Manpower planning challenges which results into barriers are identified and represented in tabular form in Table .1.

STEP 2: Structural Self-interactive matrix (SSIM) is being made by identifying relations between factors, which is an outcome of discussion with the experts and is represented in Table 5.2 with the help of symbols as per the below list:

- $\quad(i, j)$ - i represents column of table and $j$ represents rows.

- $\quad \mathrm{v}-$ forward relation ( $\mathrm{i}$ is related to $\mathrm{j}$ )

- $\quad A-$ reverse relation ( $\mathrm{j}$ is related to $\mathrm{i}$ )

- $\quad \mathrm{o}-$ no relation between $\mathrm{i}$ and $\mathrm{j}$

- $\quad x-$ represents reversible relation between $\mathrm{i}$ and $\mathrm{j}$.

STEP 3: In Structural Self- Interaction matrix (SSIM), if the value of $\mathrm{i}$ and $\mathrm{j}$ is $\mathrm{V}$, the corresponding value in Initial Reachability Matrix (IRM) becomes 1 and the reverse of it i.e. the value of $\mathrm{j}$ and $\mathrm{i}$ becomes 0 .
If in SSIM, value of $\mathrm{i}$ and $\mathrm{j}$ is $\mathrm{A}$, corresponding value in IRM becomes 0 and the value of $j$ and $i$ becomes 1 .

For value of $\mathrm{i}$ and $\mathrm{j}$ is $\mathrm{X}$ in SSIM, corresponding value in IRM becomes 1 and the value of $j$ and $i$ becomes 1 .

If in SSIM, value of $i$ and $j$ is $O$, corresponding value in IRM becomes 0 and the value of $j$ and $i$ becomes 0 .

STEP 4: Final Reachability Matrix (FRM), represented in Table 4, is constructed by finding transitivity in the matrix, which is an indirect relation between factors. If transitivity is found in the matrix, the final transitivity matrix value is put as $1 *$.

STEP 5: Further, iteration matrix is developed by segregation of reachability set, antecedent set and interaction set of both, as shown in Table 5. In this, the value is obtained from FRM. 1 in the corresponding row is taken in reachability set. 1 in the corresponding column is taken in accident set. value common in both reachability set and antecedent set is taken in Intersection set. Iteration is done afterwards, level is assigned, and the corresponding values are omitted in next iteration until all the values are omitted.

STEP 6: On the base iteration performed barriers are arranged from the most critical i.e. last level to least critical i.e. the first level and is represented in figure 2

STEP 7: Conical matrix is developed with the help of FRM along with the iteration level to find drive power and dependence power as shown in Table 9. 
STEP 8: A digraph is made in ascending order of level, which means the most critical barrier will be represented at last in the digraph, and the least critical at the top of the digraph interconnected by nodes.

STEP 9: Nodes are replaced by statements, which leads to creation of Model from the digraph. Model helps in analyzing the most and least critical factors in real time.
STEP 10: In case of any conceptual inconsistency, the above steps are repeated. Else, the process is continued.

STEP 11: MICMAC Analysis on the basis of conical matrix is analysed wherein dependency power and driving power are plotted on a graph. Graph is dividing into Autonomous, Dependent, Linkages, and Independent factors. The values of the graph were derived from conical matrix.

STEP 12: Necessary modification and theoretical discrepancies are integrated and is shown in figure

6.3 Steps involved in ISM approach are as detailed as below

Table 2 Structural self- interactive matrix

\begin{tabular}{|c|c|c|c|c|c|c|c|c|c|c|c|c|c|c|c|c|}
\hline Barrier & 16 & 15 & 14 & 13 & 12 & 11 & 10 & 9 & 8 & 7 & 6 & 5 & 4 & 3 & 2 & 1 \\
\hline 1 & o & o & $\mathrm{v}$ & o & o & o & o & o & o & o & $\mathrm{o}$ & $\mathrm{o}$ & o & $\mathrm{x}$ & $\mathrm{x}$ & - \\
\hline 2 & $\mathrm{v}$ & $\mathrm{V}$ & $\mathrm{v}$ & $\mathrm{V}$ & $\mathrm{v}$ & $\mathrm{V}$ & $\mathrm{V}$ & $\mathrm{v}$ & o & $\mathrm{x}$ & $\mathrm{x}$ & $\mathrm{x}$ & $\mathrm{x}$ & $\mathrm{x}$ & - & \\
\hline 3 & $\mathrm{O}$ & $\mathrm{x}$ & o & $\mathrm{O}$ & $\mathrm{x}$ & $\mathrm{O}$ & o & o & o & $\mathrm{x}$ & $\mathrm{X}$ & $\mathrm{V}$ & $\mathrm{V}$ & - & & \\
\hline 4 & $\mathrm{~A}$ & $\mathrm{~A}$ & o & $\mathrm{A}$ & $\mathrm{A}$ & o & o & o & o & o & $\mathrm{A}$ & $\mathrm{x}$ & - & & . & \\
\hline 5 & o & o & o & o & o & o & O & o & o & $\bar{A}$ & o & - & & & & \\
\hline 6 & $\mathrm{O}$ & $\mathrm{O}$ & $\mathrm{V}$ & o & o & o & $\mathrm{O}$ & o & o & $\mathrm{x}$ & - & & & & & \\
\hline 7 & $\mathrm{O}$ & A & o & $\mathrm{O}$ & A & $\mathrm{o}$ & $\mathrm{o}$ & $\mathrm{o}$ & $\mathrm{o}$ & - & & & & & & \\
\hline 8 & $\mathrm{O}$ & $\mathrm{O}$ & $\mathrm{v}$ & $\mathrm{O}$ & $\mathrm{o}$ & $\mathrm{O}$ & $\mathrm{O}$ & $\mathrm{x}$ & - & & & & & . & & \\
\hline 9 & $\mathrm{~V}$ & $\mathrm{o}$ & $\mathrm{v}$ & $\mathrm{V}$ & $\mathrm{o}$ & $\mathrm{o}$ & $\mathrm{o}$ & - & & & & & & & & \\
\hline 10 & $\mathrm{~V}$ & $\mathrm{o}$ & $\mathrm{v}$ & $\mathrm{o}$ & A & $\mathrm{O}$ & - & & & & & & & & & \\
\hline 11 & $\mathrm{O}$ & $\mathrm{o}$ & $\mathrm{V}$ & A & $\mathrm{o}$ & - & & & & & & & & & & \\
\hline 12 & 0 & o & $\mathrm{v}$ & o & - & & & & & & & & & & & \\
\hline 13 & o & o & o & - & & & & & & & & & & & & \\
\hline 14 & $\mathrm{O}$ & o & - & & & & & & & & & & & & & \\
\hline 15 & 0 & - & & & & & & & & & & & &. & . & \\
\hline 16 & - & & & & & & & & & & & & & & & \\
\hline
\end{tabular}

Table 3 Initial Reachability Matrix (IRM)

\begin{tabular}{|l|l|l|l|l|l|l|l|l|l|l|l|l|l|l|l|l|}
\hline Barrier & 1 & 2 & 3 & 4 & 5 & 6 & 7 & 8 & 9 & 10 & 11 & 12 & 13 & 14 & 15 & 16 \\
\hline 1 & 1 & 1 & 1 & 0 & 0 & 0 & 0 & 0 & 0 & 0 & 0 & 0 & 0 & 1 & 0 & 0 \\
\hline 2 & 1 & 1 & 1 & 1 & 1 & 1 & 1 & 0 & 1 & 1 & 1 & 1 & 1 & 1 & 1 & 1 \\
\hline 3 & 1 & 1 & 1 & 1 & 1 & 1 & 1 & 0 & 0 & 0 & 0 & 1 & 0 & 0 & 1 & 0 \\
\hline 4 & 0 & 1 & 0 & 1 & 1 & 0 & 0 & 0 & 0 & 0 & 0 & 0 & 0 & 0 & 0 & 0 \\
\hline 5 & 0 & 1 & 0 & 1 & 1 & 0 & 0 & 0 & 0 & 0 & 0 & 0 & 0 & 0 & 0 & 0 \\
\hline 6 & 0 & 1 & 1 & 1 & 0 & 1 & 1 & 0 & 0 & 0 & 0 & 0 & 0 & 1 & 0 & 0 \\
\hline 7 & 0 & 1 & 1 & 0 & 1 & 1 & 1 & 0 & 0 & 0 & 0 & 0 & 0 & 0 & 0 & 0 \\
\hline 8 & 0 & 0 & 0 & 0 & 0 & 0 & 0 & 1 & 1 & 0 & 0 & 0 & 0 & 1 & 0 & 0 \\
\hline 9 & 0 & 0 & 0 & 0 & 0 & 0 & 0 & 1 & 1 & 0 & 0 & 0 & 1 & 1 & 1 & 0 \\
\hline 10 & 0 & 0 & 0 & 0 & 0 & 0 & 0 & 0 & 0 & 1 & 0 & 0 & 0 & 1 & 0 & 1 \\
\hline 11 & 0 & 0 & 0 & 0 & 0 & 0 & 0 & 0 & 0 & 0 & 1 & 0 & 0 & 1 & 0 & 0 \\
\hline 12 & 0 & 0 & 1 & 1 & 0 & 0 & 1 & 0 & 0 & 1 & 0 & 1 & 0 & 1 & 0 & 0 \\
\hline 13 & 0 & 0 & 0 & 1 & 0 & 0 & 0 & 0 & 0 & 0 & 1 & 0 & 1 & 0 & 0 & 0 \\
\hline 14 & 0 & 0 & 0 & 0 & 0 & 0 & 0 & 0 & 0 & 0 & 0 & 0 & 0 & 1 & 0 & 0 \\
\hline 15 & 0 & 0 & 1 & 1 & 1 & 0 & 1 & 0 & 0 & 0 & 0 & 0 & 0 & 0 & 1 & 0 \\
\hline 16 & 0 & 0 & 0 & 1 & 0 & 0 & 0 & 0 & 0 & 0 & 0 & 0 & 0 & 0 & 0 & 1 \\
\hline
\end{tabular}


Table 4 Final Reachability Matrix (FRM)

\begin{tabular}{|l|l|l|l|l|l|l|l|l|l|l|l|l|l|l|l|l|}
\hline Barrier & 1 & 2 & 3 & 4 & 5 & 6 & 7 & 8 & 9 & 10 & 11 & 12 & 13 & 14 & 15 & 16 \\
\hline 1 & 1 & 1 & 1 & $1^{*}$ & $1^{*}$ & $1^{*}$ & $1^{*}$ & 0 & $1^{*}$ & $1^{*}$ & $1^{*}$ & $1^{*}$ & $1^{*}$ & 1 & $1^{*}$ & $1^{*}$ \\
\hline 2 & 1 & 1 & 1 & 1 & 1 & 1 & 1 & $1^{*}$ & 1 & 1 & 1 & 1 & 1 & 1 & 1 & 1 \\
\hline 3 & 1 & 1 & 1 & 1 & 1 & 1 & 1 & 0 & $1^{*}$ & $1^{*}$ & $1^{*}$ & 1 & $1^{*}$ & $1^{*}$ & 1 & $1^{*}$ \\
\hline 4 & $1^{*}$ & 1 & $1^{*}$ & 1 & 1 & $1^{*}$ & $1^{*}$ & 0 & $1^{*}$ & $1^{*}$ & $1^{*}$ & $1^{*}$ & $1^{*}$ & $1^{*}$ & $1^{*}$ & $1^{*}$ \\
\hline 5 & $1^{*}$ & 1 & $1^{*}$ & 1 & 1 & $1^{*}$ & $1^{*}$ & 0 & $1^{*}$ & $1^{*}$ & $1^{*}$ & $1^{*}$ & $1^{*}$ & $1^{*}$ & $1^{*}$ & $1^{*}$ \\
\hline 6 & $1^{*}$ & 1 & 1 & 1 & $1^{*}$ & 1 & 1 & 0 & $1^{*}$ & $1^{*}$ & $1^{*}$ & $1^{*}$ & $1^{*}$ & 1 & $1^{*}$ & $1^{*}$ \\
\hline 7 & $1^{*}$ & 1 & 1 & $1^{*}$ & 1 & 1 & 1 & $1^{*}$ & $1^{*}$ & $1^{*}$ & $1^{*}$ & $1^{*}$ & $1^{*}$ & $1^{*}$ & $1^{*}$ & $1^{*}$ \\
\hline 8 & 0 & 0 & 0 & 0 & 0 & 0 & 0 & 1 & 1 & 0 & 0 & 0 & $1^{*}$ & 1 & $1^{*}$ & 0 \\
\hline 9 & 0 & 0 & $1^{*}$ & $1^{*}$ & $1^{*}$ & 0 & $1^{*}$ & 1 & 1 & 0 & $1^{*}$ & 0 & 1 & 1 & 1 & 0 \\
\hline 10 & $1^{*}$ & 0 & 0 & $1^{*}$ & 0 & 0 & 0 & 0 & 0 & 1 & 0 & 0 & 0 & 1 & 0 & 1 \\
\hline 11 & $1^{*}$ & 0 & 0 & 0 & 0 & 0 & 0 & 0 & 0 & 0 & 1 & 0 & 0 & 1 & 0 & 0 \\
\hline 12 & $1^{*}$ & $1^{*}$ & 1 & 1 & $1^{*}$ & $1^{*}$ & 1 & 0 & 0 & 1 & 0 & 1 & 0 & 1 & $1^{*}$ & 0 \\
\hline 13 & 0 & $1^{*}$ & 0 & 1 & $1^{*}$ & 0 & 0 & 0 & 0 & 0 & 1 & 0 & 1 & $1^{*}$ & 0 & 0 \\
\hline 14 & 0 & 0 & 0 & 0 & 0 & 0 & 0 & 0 & 0 & 0 & 0 & 0 & 0 & 1 & 0 & 0 \\
\hline 15 & $1^{*}$ & $1^{*}$ & 1 & 1 & 1 & $1^{*}$ & 1 & 0 & 0 & 0 & 0 & $1^{*}$ & 0 & 0 & 1 & 0 \\
\hline 16 & 0 & $1^{*}$ & 0 & 1 & $1^{*}$ & 0 & 0 & 0 & 0 & 0 & 0 & 0 & 0 & 0 & 0 & 1 \\
\hline
\end{tabular}

Table 5 Iteration I (Level Partitions of Drivers)

\begin{tabular}{|c|c|c|c|c|}
\hline s. no & Reachability set & Antecedent set & Intersection set & level \\
\hline 1 & $\begin{array}{l}1,2,3,4,5,6,7,9,10,11,12, \\
13,14,15,16\end{array}$ & $\begin{array}{l}1,2,3,4,5,6,7,10,11,12, \\
15,\end{array}$ & $\begin{array}{l}1,2,3,4,5,6,7,10, \\
11,12,15,\end{array}$ & \\
\hline 2 & $\begin{array}{l}1,2,3,4,5,6,7,8,9,10,11,12 \\
13,14,15,16\end{array}$ & $\begin{array}{l}1,2,3,4,5,6,7,12,13,15, \\
16,\end{array}$ & $\begin{array}{l}1,2,3,4,5,6,7,12, \\
13,15,16,\end{array}$ & \\
\hline 3 & $\begin{array}{l}1,2,3,4,5,6,7,9,10,11,12, \\
13,14,15,16\end{array}$ & $1,2,3,4,5,6,7,9,12,15$ & $\begin{array}{l}1,2,3,4,5,6,7,9, \\
12,15,\end{array}$ & \\
\hline 4 & $\begin{array}{l}1,2,3,4,5,6,7,9,10,12,13 \\
14,15,16\end{array}$ & $\begin{array}{l}1,2,3,4,5,6,7,9,10,12, \\
13,15,16\end{array}$ & $\begin{array}{l}1,2,3,4,5,6,7,9, \\
10,12,13,15,16,\end{array}$ & \\
\hline 5 & $\begin{array}{l}1,2,3,4,5,6,7,9,10,11,12, \\
13,14,15,16,\end{array}$ & $\begin{array}{l}1,2,3,4,5,6,7,9,12,13, \\
15,16,\end{array}$ & $\begin{array}{l}1,2,3,4,5,6,7,9, \\
12,13,15,16,\end{array}$ & \\
\hline 6 & $\begin{array}{l}1,2,3,4,5,6,7,9,10,11,12, \\
13,14,15,16,\end{array}$ & $1,2,3,4,5,6,7,12,15$ & $\begin{array}{l}1,2,3,4,5,6,7,12, \\
15,\end{array}$ & \\
\hline 7 & $\begin{array}{l}1,2,3,4,5,6,7,8,9,10,11,12 \\
13,14,15,16,\end{array}$ & $1,2,3,4,5,6,7,9,12,15$ & $\begin{array}{l}1,2,3,4,5,6,7, \\
9,12,15,\end{array}$ & \\
\hline 8 & $8,9,13,14,15$ & $2,7,8,9,16$, & 8,9 & \\
\hline 9 & $3,4,5,7,8,9,13,14,15$, & $1,2,3,4,5,6,7,8,9$ & $3,4,5,7,8,9$ & \\
\hline 10 & $1,4,10, \quad 14,16$ & $1,2,3,4,5,6,7, \quad 10, \quad 12$ & $1,4,10$ & \\
\hline 11 & $1,11,14$ & $1,2,3,4,5,6,7,9,11,13$ & 1,11 & \\
\hline 12 & $1,2,3,4,5,6,7,10,12,14,15$ & $1,2,3,4,5,6,7, \quad 12,15,16$ & $\begin{array}{l}1,2,3,4,5,6,7, \\
12,15,\end{array}$ & \\
\hline 13 & $2,4,5,11,13,14$ & $1,2,3,4,5,6,7,8,9,13$ & $2,4,5,13$ & \\
\hline 14 & 14 & $\begin{array}{l}1,2,3,4,5,6,7,8,9,10,11, \\
12,13,14,\end{array}$ & 14, & I \\
\hline 15 & $1,2,3,4,5,6,7,12,15$, & $\begin{array}{l}1,2,3,4,5,6,7,8,9,12, \\
15,\end{array}$ & $\begin{array}{l}1,2,3,4,5,6,7,12, \\
15,\end{array}$ & I \\
\hline 16 & $2,4,5,16$ & $1,2,3,4,5,6,7,10, \quad 16$ & $2,4,5,16$ & $\mathrm{I}$ \\
\hline
\end{tabular}


Table 6. Iteration II (Level Partitions of Drivers)

\begin{tabular}{|l|l|l|l|l|}
\hline s. no & Reachability set & Antecedent set & Intersection set & level \\
\hline 1 & $\begin{array}{l}1,2,3,4,5,6,7,9,10,11, \\
12,13,\end{array}$ & $1,2,3,4,5,6,7,10,11,12$, & $\begin{array}{l}1,2,3,4,5,6,7, \\
10,11,12,\end{array}$ & \\
\hline 2 & $\begin{array}{l}1,2,3,4,5,6,7,8,9,10,11, \\
12,13,\end{array}$ & $1,2,3,4,5,6,7,12,13$, & $\begin{array}{l}1,2,3,4,5,6,7, \\
12,13,\end{array}$ & \\
\hline 3 & $\begin{array}{l}1,2,3,4,5,6,7,9,10,11, \\
12,13,\end{array}$ & $1,2,3,4,5,6,7,9,12$, & $\begin{array}{l}1,2,3,4,5,6,7, \\
9,12,\end{array}$ & \\
\hline 4 & $1,2,3,4,5,6,7,9,10,12$, & $1,2,3,4,5,6,7,9,10,12$, & $1,2,3,4,5,6,7$, \\
& 13, & 13, & II \\
\hline 5 & $1,2,3,4,5,6,7,9,10,11$, & $1,2,3,4,5,6,7,9,12,13$, & $1,2,3,4,5,6,7$, & \\
& 12,13, & & $9,12,13$, & \\
\hline 6 & $1,2,3,4,5,6,7,9,10,11$, & $1,2,3,4,5,6,7,12$, & $1,2,3,4,5,6,7$, & \\
& 12,13, & & 12, & \\
\hline 7 & $1,2,3,4,5,6,7,8,9,10,11$, & $1,2,3,4,5,6,7,9,12$, & $9,12,4,5,6,7$, & \\
& 12,13, & & 8,9, & \\
\hline 8 & $8,9,13$, & $2,7,8,9$, & $3,4,5,7,8,9$, & \\
\hline 9 & $3,4,5,7,8,9,13$, & $1,2,3,4,5,6,7,8,9$, & II \\
\hline 10 & $1,4,10$, & $1,2,3,4,5,6,7,10,12$, & $1,4,10$, & II \\
\hline 11 & 1,11, & $1,2,3,4,5,6,7,9,11,13$, & 1,11, & \\
\hline 12 & $1,2,3,4,5,6,7,10,12$, & $1,2,3,4,5,6,7,12$, & $1,2,3,4,5,6,7$, & \\
& & & 12, & \\
\hline 13 & $2,4,5,11,13$, & $1,2,3,4,5,6,7,8,9,13$, & $2,4,5,13$, & \\
\hline
\end{tabular}

Table 7 Iteration III (Level Partitions of Drivers)

\begin{tabular}{|l|l|l|l|l|}
\hline s. no & Reachability set & Antecedent set & Intersection set & level \\
\hline 1 & $1,2,3,5,6,7,9,12,13$, & $1,2,3,5,6,7,12$, & $1,2,3,5,6,7, \quad 12$, & \\
\hline 2 & $1,2,3,5,6,7,8,9,12,13$, & $1,2,3,5,6,7,12,13$, & $1,2,3,5,6,7,12,13$, & \\
\hline 3 & $1,2,3,5,6,7,9,12,13$, & $1,2,3,5,6,7,9,12$, & $1,2,3,5,6,7,9,12$, & \\
\hline 5 & $1,2,3,5,6,7,9,12,13$, & $1,2,3,5,6,7,9,12,13$, & $\begin{array}{l}1,2,3,5,6,7,9,12, \\
13,\end{array}$ & III \\
& & & $1,2,3,5,6,7,12$, & \\
\hline 6 & $1,2,3,5,6,7,9,12,13$, & $1,2,3,5,6,7,12$, & $1,2,3,5,6,7,9,12$, & \\
\hline 7 & $1,2,3,5,6,7,8,9,12,13$, & $1,2,3,5,6,7,9,12,13$, & \\
\hline 8 & $8,9,13$, & $2,7,8,9$, & 8,9, & \\
\hline 9 & $3,5,7,8,9,13$, & $1,2,3,5,6,7,8,9$, & $3,5,7,8,9$, & \\
\hline 12 & $1,2,3,5,6,7,12$, & $1,2,3,5,6,7,12$, & $1,2,3,5,6,7,12$, & III \\
\hline 13 & $2,5,13$, & $1,2,3,5,6,7,8,9,13$, & $2,5,13$, & III \\
\hline
\end{tabular}

Table 8 Iteration IV (Level Partitions of Drivers)

\begin{tabular}{|l|l|l|l|l|}
\hline s. no & Reachability set & Antecedent set & Intersection set & level \\
\hline 1 & $1,2,3,6,7,9$, & $1,2,3,6,7$, & $1,2,3,6,7$, & \\
\hline 2 & $1,2,3,6,7,8,9$, & $1,2,3,6,7$, & $1,2,3,6,7$, & \\
\hline 3 & $1,2,3,6,7,9$, & $1,2,3,6,7,9$, & $1,2,3,6,7,9$, & IV \\
\hline 6 & $1,2,3,6,7,9$, & $1,2,3,6,7$, & $1,2,3,6,7$, & \\
\hline 7 & $1,2,3,6,7,8,9$, & $1,2,3,6,7,9$, & $1,2,3,6,7,9$, & \\
\hline 8 & 8,9, & $1,2,7,8,9$, & 8,9, & IV \\
\hline 9 & $3,7,8,9$, & $1,2,3,6,7,8,9$, & $3,7,8,9$, & IV \\
\hline
\end{tabular}


Table 9 Iteration V (Level Partitions of Drivers)

\begin{tabular}{|l|l|l|l|l|}
\hline s. no & Reachability set & Antecedent set & Intersection set & level \\
\hline 1 & $1,2, \quad 6,7$, & $1,2, \quad 6,7$, & $1,2,6,7$, & V \\
\hline 2 & $1,2, \quad 6,7$, & $1,2, \quad 6,7$, & $1,2,6,7$, & V \\
\hline 6 & $1,2, \quad 6,7$, & $1,2, \quad 6,7$, & $1,2,6,7$, & V \\
\hline 7 & $1,2, \quad 6,7$, & $1,2, \quad 6,7$, & $1,2,6,7$, & V \\
\hline
\end{tabular}

Tables 10 Conical Matrix

\begin{tabular}{|l|l|l|l|l|l|l|l|l|l|l|l|l|l|l|l|l|l|l|}
\hline Barrier & 7 & 6 & 2 & 1 & 9 & 8 & 3 & 13 & 12 & 5 & 11 & 10 & 4 & 16 & 15 & 14 & $\begin{array}{l}\text { Driving } \\
\text { power }\end{array}$ & $\begin{array}{l}\text { Ran } \\
\mathrm{k}\end{array}$ \\
\hline 7 & 1 & 1 & 1 & 1 & 1 & 1 & 1 & 1 & 1 & 1 & 1 & 1 & 1 & 1 & 1 & 1 & 16 & 1 \\
\hline 6 & 1 & 1 & 1 & 1 & 1 & 0 & 1 & 1 & 1 & 1 & 1 & 1 & 1 & 1 & 1 & 1 & 15 & 2 \\
\hline 2 & 1 & 1 & 1 & 1 & 1 & 1 & 1 & 1 & 1 & 1 & 1 & 1 & 1 & 1 & 1 & 1 & 16 & 1 \\
\hline 1 & 1 & 1 & 1 & 1 & 1 & 0 & 1 & 1 & 1 & 1 & 1 & 1 & 1 & 1 & 1 & 1 & 15 & 2 \\
\hline 9 & 1 & 0 & 0 & 0 & 1 & 1 & 1 & 1 & 0 & 1 & 1 & 0 & 1 & 0 & 1 & 1 & 10 & 4 \\
\hline 8 & 0 & 0 & 0 & 0 & 1 & 1 & 0 & 1 & 0 & 0 & 0 & 0 & 0 & 0 & 1 & 1 & 5 & 7 \\
\hline 3 & 1 & 1 & 1 & 1 & 1 & 0 & 1 & 1 & 1 & 1 & 1 & 1 & 1 & 1 & 1 & 1 & 15 & 2 \\
\hline 13 & 0 & 0 & 1 & 0 & 0 & 0 & 0 & 1 & 0 & 1 & 1 & 0 & 1 & 0 & 0 & 1 & 6 & 6 \\
\hline 12 & 1 & 1 & 1 & 1 & 0 & 0 & 1 & 0 & 1 & 1 & 0 & 1 & 1 & 0 & 1 & 1 & 11 & 3 \\
\hline 5 & 1 & 1 & 1 & 1 & 1 & 0 & 1 & 1 & 1 & 1 & 1 & 1 & 1 & 1 & 1 & 1 & 15 & 2 \\
\hline 11 & 0 & 0 & 0 & 1 & 0 & 0 & 0 & 0 & 0 & 0 & 1 & 0 & 0 & 0 & 0 & 1 & 3 & 9 \\
\hline 10 & 0 & 0 & 0 & 1 & 0 & 0 & 0 & 0 & 0 & 0 & 0 & 1 & 1 & 1 & 0 & 1 & 5 & 7 \\
\hline 4 & 1 & 1 & 1 & 1 & 1 & 0 & 1 & 1 & 1 & 1 & 1 & 1 & 1 & 1 & 1 & 1 & 15 & 2 \\
\hline 16 & 0 & 0 & 1 & 0 & 0 & 0 & 0 & 0 & 0 & 1 & 0 & 0 & 1 & 1 & 0 & 0 & 4 & 8 \\
\hline 15 & 1 & 1 & 1 & 1 & 0 & 0 & 1 & 0 & 1 & 1 & 0 & 0 & 1 & 0 & 1 & 0 & 9 & 5 \\
\hline 14 & 0 & 0 & 0 & 0 & 0 & 0 & 0 & 0 & 0 & 0 & 0 & 0 & 0 & 0 & 0 & 1 & 1 & 10 \\
\hline $\begin{array}{l}\text { Dependency } \\
\text { power }\end{array}$ & 1 & 9 & 1 & 1 & 9 & 4 & 1 & 10 & 9 & 1 & 10 & 9 & 1 & 9 & 11 & 14 & 161 & \\
\hline Rank & 0 & & 1 & 1 & & & 0 & & & 2 & & & 3 & & & & & \\
\hline
\end{tabular}

Digraph Representation for affecting drivers

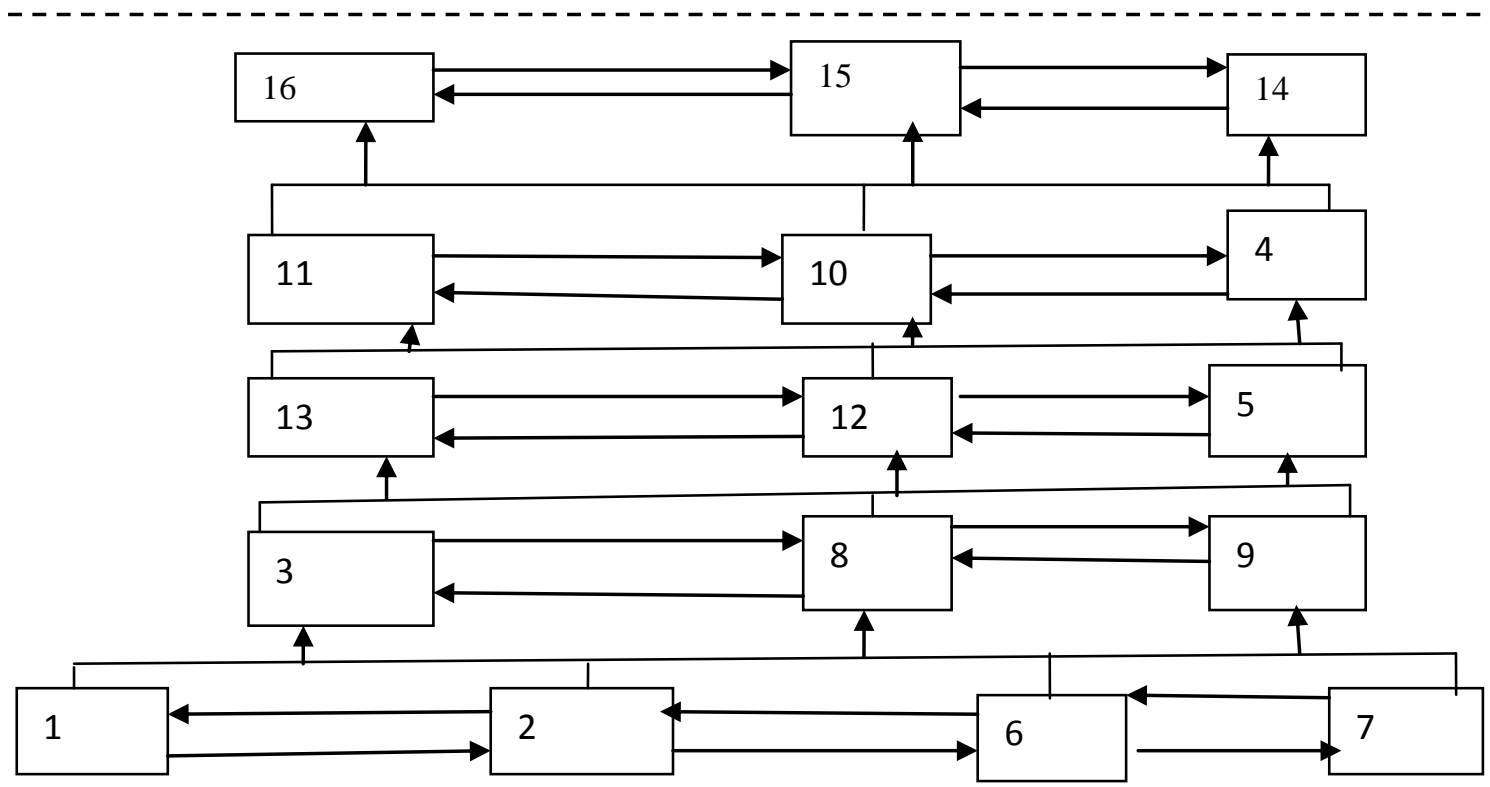


ISM Model for affecting drivers

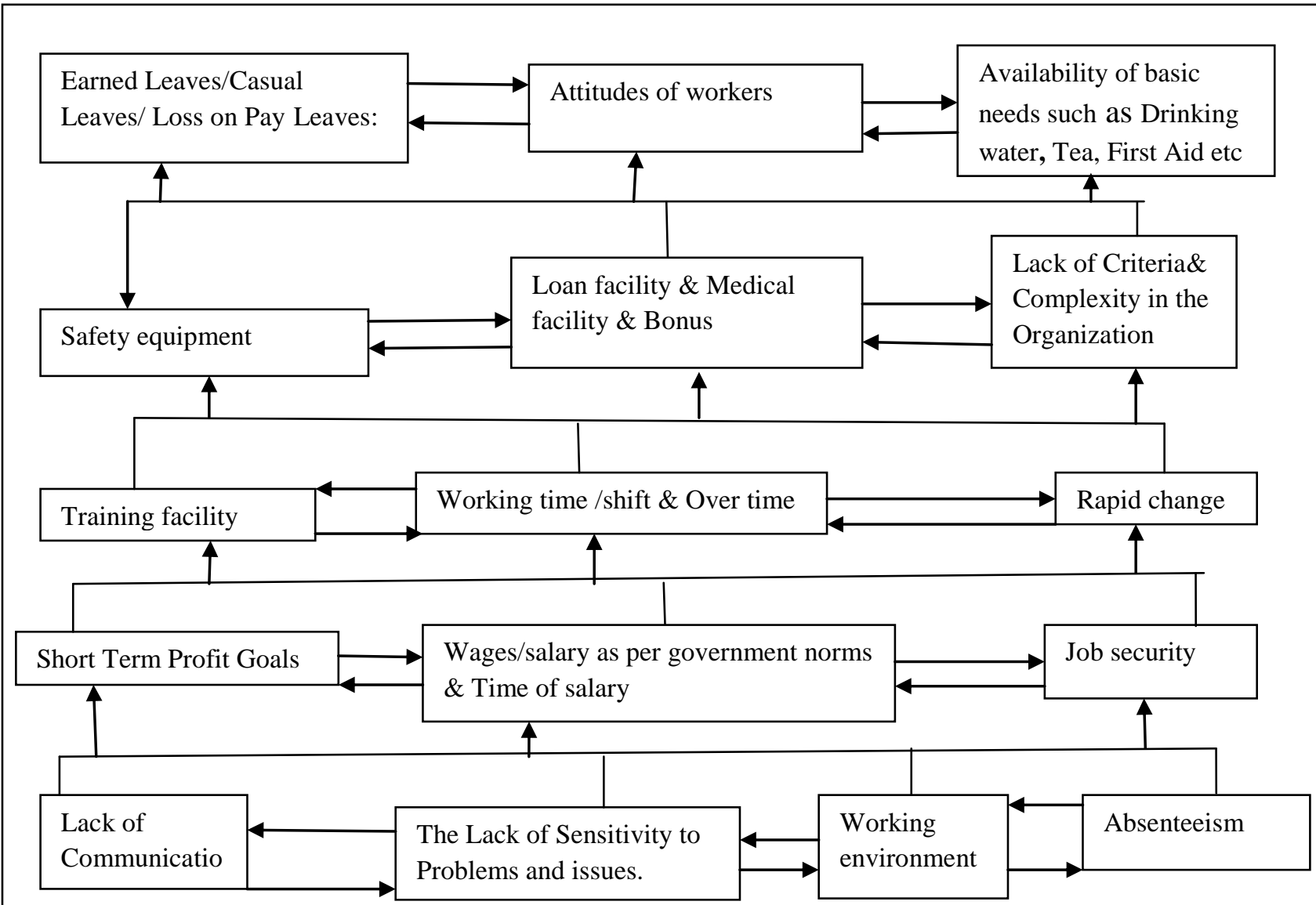

\section{MICMAC ANALYSIS}

In this analysis, analysis is done between the driver power and dependence power of the element. MICMAC analysis graphically shows the driving and dependency power of the elements, which helps in analyzing the strong and weak driving power. In this analysis, a graph is plotted between driver power and dependence power, $\mathrm{X}$-axis represents the dependency power and $y$-axis represents the driver power. The graph is plotted on the basis of conical matrix. The drivers are further categorised in four categories detailed as below:

$>$ Autonomous driver

$>$ Dependent driver

$>$ Linkage driver

\section{Independent driver}

Autonomous driver shows weak drive power and weak dependence power. Dependent driver explain strong dependency power and weak driver power. Linkage explains both strong driving and dependence power. It is unstable. Any change in this may give positive or negative effect on manpower planning. Independent drive explains strong driver power and weak dependence power.

$>$ Independent CSFs

$>$ Autonomous barriers -8

$>$ Dependent barriers. - 10111316

$>\quad$ Linkage barriers 12345679121 
International Journal of Engineering Applied Sciences and Technology, 2019

Vol. 4, Issue 4, ISSN No. 2455-2143, Pages 365-377

Published Online August 2019 in IJEAST (http://www.ijeast.com)

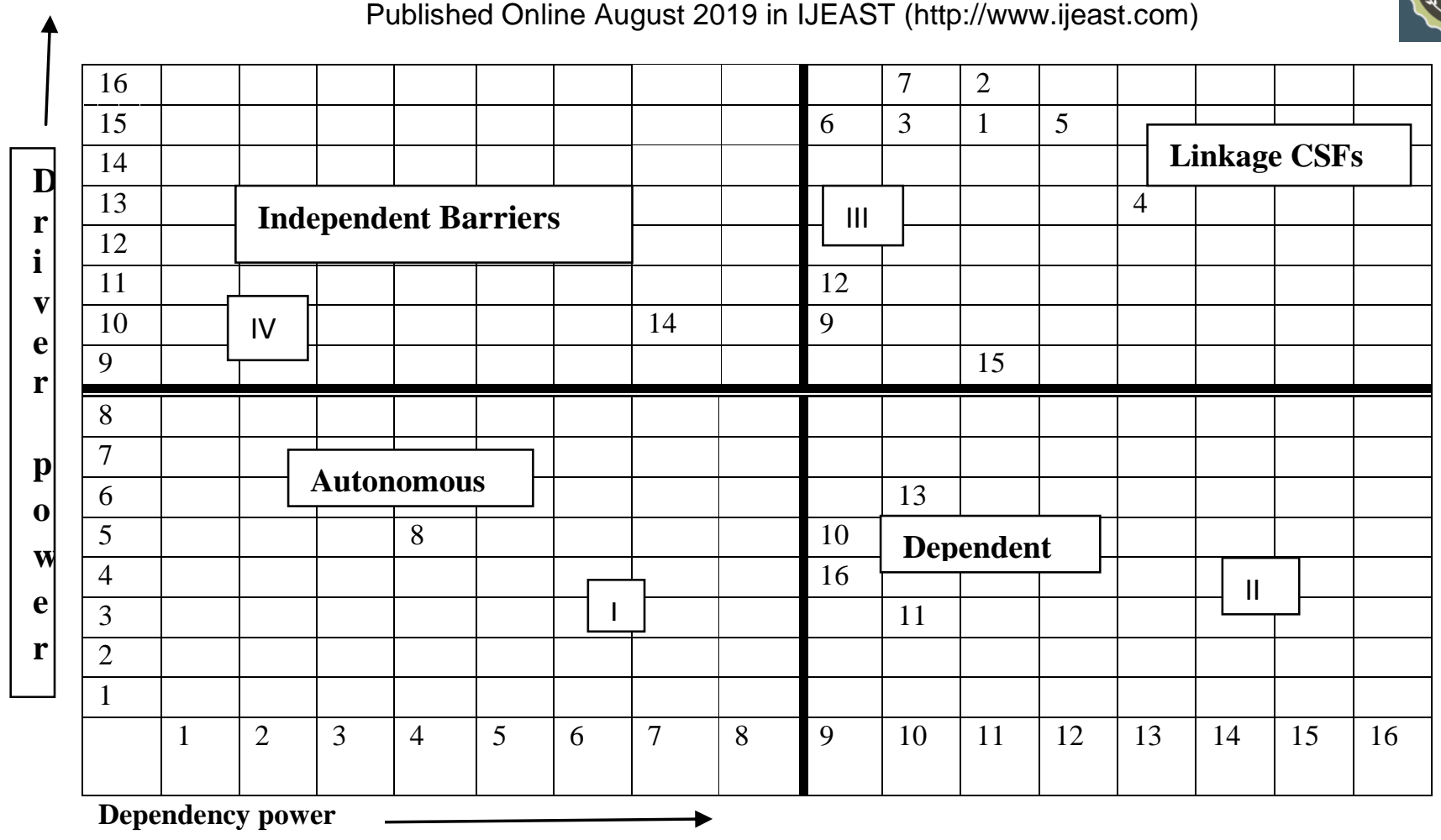

Figure 3 MICMAC Analysis

Table 11 level of Partitions of Drivers after Iterations

\begin{tabular}{|l|l|l|}
\hline S. no & Barriers & Level \\
\hline 1 & Lack of Communication & V \\
\hline 2 & $\begin{array}{l}\text { The Lack of sensitivity about problem and solution of } \\
\text { the issues. }\end{array}$ & V \\
\hline 3 & The short team profit goal & IV \\
\hline 4 & Lack of Criteria\& Complexity of the Organization & II \\
\hline 5 & Rapid change & III \\
\hline 6 & Working environment & V \\
\hline 7 & Absenteeism & V \\
\hline 8 & $\begin{array}{l}\text { Wages/salary as per government norms\& Time of } \\
\text { salary }\end{array}$ & IV \\
\hline 9 & Job security & IV \\
\hline 10 & Loan facility\& Medical facility\& Bonus & II \\
\hline 11 & Safety equipment & II \\
\hline 12 & Working time/shift\& Over time & III \\
\hline 13 & Training facility & III \\
\hline 14 & Attitudes of workers & I \\
\hline 15 & Earned Leaves/Casual Leaves/ Loss on Pay Leaves: & I \\
\hline 16 & Availability of basic needs such as Drinking water, \\
& Tea, First Aid etc & \\
\hline
\end{tabular}




\section{International Journal of Engineering Applied Sciences and Technology, 2019 Vol. 4, Issue 4, ISSN No. 2455-2143, Pages 365-377 \\ Published Online August 2019 in IJEAST (http://www.ijeast.com)}

\section{CONCLUSION}

On the basis of the above elaborate explanation, it can be concluded that herein developed model is important to understand the implementation of manpower planning in small scale industry. In the studied model, drivers have been partitioned in various levels such that the one in charge of manpower planning is aware of the importance of various drivers for betterment of the industry in terms of productivity and the apt methodology for implementing them. Further, total sixteen types of factors were studied and the interaction between the identifiable factors was analyzed with the help of model developed, which is detailed in fig 6.2.

In this context, it has submitted that drivers such as Lack of communication, the lack of sensitivity about problem and solution of the issues, absenteeism, working environment, shortterm profit goal, wages, / salary as per the government norms and time of credit of salary, Job security, are the most critical and are placed at the bottom of the model.

The drivers' viz. Rapid change, Working time/ shifts/ overtime allowances, training facility, Safety equipment, loan facility, and medical facility, bonuses, Lack of Criteria\& Complexity of the Organization, have placed at an intermediate level of the developed model.

Further the drivers viz. Attitude of workers, Availability of basic facilities such as drinking water, tea, first aid kits, Earned Leaves/Casual Leaves/ Loss on Pay Leaves are least critical and placed at the top in the developed model.

In addition to this, the interrelationships among the drivers have expected to provide guidance to management for proper understanding of the complex situation and make effective implementation plan.

Further, form the MICMAC analysis as shown in figure 6.3 , it is evident that drivers viz. Attitudes of the workers has strong driving power and weak dependency power and are termed as Independent Drives. This drive has most driving power and least dependency, which results in driver becoming more important drive for the implementation of manpower planning in a small-scale industry.

The Lack of communication, the lack of sensitivity about the problem and solution of the issues, short term profit goals, lack of criteria and complexity of the organization, rapid Change, working environment, absenteeism, Job Security, working times, shifts and overtime allowances, and, various kinds of Leaves have strong driving as well as strong dependency power. It is a part of linkage drive. These are unstable in nature. Any change in theses drives will lead change in other drive as well as themselves. Theses change can be positive or negative in adoption of manpower planning in small scale industry.

Loan facility\& Medical facility\& Bonus, Safety equipment, Training facility availability of basic needs such as drinking water, tea and first aid are dependent drive. It has strong dependency power and weak driving power.

Wages and salary and its time of credit, is Autonomous drive. They have weak driving power and weak dependency power.

Therefore, we have seen that the model developed herein is an effective way of proper implementation of manpower planning by the way of scientific study of data. Further, the graph plotted between the driving factors and dependency factors gives us an idea about the level of rigidity and complexity involved in manpower planning and interdependence and intra-dependence of factors which can lead to betterment in the productivity in a small scale industry. The analysis also gives an idea on the factors that may be considered before planning a change in the manpower management in a small scale industry and how mismanagement in it can lead to the collapse of industry. The model can be further deployed in an industry and the output may be matched on a real time basis to further analyze the model and make it precise.

\section{REFERENCE}

1. Abdullah, Zaini, Nilufar Ahsan, and Syed Shah Alam. (2009) "The effect of human resource management practices on business performance among private companies in Malaysia." International Journal of Business and Management 4.6 (pp- 65-72)

2. Koltnerová, Kristína, Andrea Chlpeková, and Jana Samáková (2012) "The importance of human resource planning in industrial enterprises." Research Papers Faculty of Materials Science and Technology Slovak University of Technology (pp. 62-67)

3. Adekunle, S.N Lucent-Iwhiwhu, H.E.O (2014) "Conceptual Approach to man power planning in organization" Journal of management governance/ volume 6 (ISSN 2277-0089).

4. Dr. Mohammad Tufial Khan (2018) "Manpower planning in educational instutions" IJOBQEAAMR volume -5 (ISSN NO-2349-5677)

5. Muhammad Ali, Zulfqar and Javed Iqbal (2012) "Human resources planning: Akey 


\section{International Journal of Engineering Applied Sciences and Technology, 2019 \\ Vol. 4, Issue 4, ISSN No. 2455-2143, Pages 365-377 \\ Published Online August 2019 in IJEAST (http://www.ijeast.com)}

tointernal and external fit" African journal of business Management vol 6(27) (pp7983-7941)

6. Helavalada Wajiga (2017) "Significance of Manpower Planning For Effective Utilization of Human Resources in an Organization: A Conceptual Approach" International Journal of Business and Management Invention ISSN (Online): 2319 - 8028, ISSN (Print): $2319-801 \mathrm{X}$ www.ijbmi.org || Volume 6 ( PP-16-22)

7. Ali, Muhammad, Zulfqar Ahmad, and Javed Iqbal. (2012): "Human resource planning: A key to internal and external fit." African Journal of Business Management 6.27 (pp- 7938-7941)

8. A. Mehlmann. (nov, 1980), An Approach to Optimal Recruitment and Transition Strategies for Manpower Systems using Dynamic Programming.Journal of the optimal research society. Vol.31, no.11 (pp. 1009-1015).

9. Attar, A. A., A. K. Gupta, and D. B. Desai. (2012) "A study of various factors affecting labour productivity and methods to improve it" IOSR Journal of Mechanical and Civil Engineering (pp11-14)

10. Talib, Faisal, Zillur Rahman, and M. N. Qureshi. (2011) "Analysis of interaction among the barriers to total quality management implementation using interpretive structural modeling approach." Benchmarking: An International Journal 18.4 (pp- 563-587)

11. Helavalada Wajiga, Julius Tumba Ndaghu, (2003) "Significance of Manpower Planning For Effective Utilization of Human Resources in an Organization: A Conceptual Approach" International Journal of Business and Management Invention ISSN (Online): 2319 - 8028, ISSN (Print): $2319-801 \mathrm{X}$

12. Fagbenle, Olabosipo I., Ayodeji Ogunde, and J. D. Owolabi. (2011) "Factors affecting the performance of labour in Nigerianconstructionsites" Mediterranean journal of social sciences2.2 (pp- 251-257)

13. Bag, Surajit, and Neeraj Anand.(2014) "Modeling green supply chain management framework using ISM and MICMAC analysis." African Journal of Business Management 8.22 (pp- 10531065)

14. Bag, Surajit, and Neeraj Anand (2014) "Modeling green supply chain management framework using ISM and MICMAC analysis." African Journal of
Business Management 8.22 (pp-10531065)

15. Guerry, Marie-Anne, and Tim De Feyter (2009) "Markovian approaches in modelling workforce systems." Journal of Current Issues in Finance, Business and Economics 2.4 (pp- 351-370)

16. Grassmann, Winfried K., Michael I. Taksar, and Daniel P. Heyman. (1985): "Regenerative analysis and steady state distributions for Markov chains." Operations Research 33.5(pp1107-1116)

17. Huselid, Mark A.(1995) "The impact of human resource management practices on turnover, productivity, and corporate financial performance." Academy of management journal 38.3 (pp-635-672)

18. Ahmad, Sohel, and Roger G. Schroeder.(2003) "The impact of human resource management practices on operational performance: recognizing country and industry differences." Journal of operations Management 21.1 (pp- 1943)

19. California Management Review, Vol. 40, No. 2,( pp. 96-1240)

20. Mehlmann, Alexander. (1980): "An approach to optimal recruitment and transition strategies for manpower systems using dynamic programming." Journal of the Operational Research Society ( PP1009-1015)

21. Visel, Axel, et al. (2009) "ChIP-seq accurately predicts tissue-specific activity of enhancers." Nature 457.7231 (2009): 854.

22. Wright, Patrick M., Timothy M. Gardner, and Lisa M. Moynihan. (2003) "The impact of HR practices on the performance of business units." Human Resource Management Journal 13.3 (pp21-36) 
International Journal of Engineering Applied Sciences and Technology, 2019 Vol. 4, Issue 4, ISSN No. 2455-2143, Pages 365-377

Published Online August 2019 in IJEAST (http://www.ijeast.com) 